\title{
EFFECT OF BIOMECHANICAL PREPARATION AND CALCIUM HYDROXIDE PASTES ON THE ANTISEPSIS OF ROOT CANAL SYSTEMS IN DOGS
}

\author{
AÇÃO DO PREPARO BIOMECÂNICO E DE PASTAS À BASE DE HIDRÓXIDO DE CÁLCIO \\ NA ANTI-SEPSIA DO SISTEMA DE CANAIS RADICULARES DE CÃES
}

Janir Alves SOARES ${ }^{1}$, Mario Roberto LEONARDO², Léa Assed Bezerra da SILVA³ , Mário TANOMARU FILHO ${ }^{4}$ Izabel Yoko ITO $^{5}$

1- DDS, MSc, PhD. Chairman, Discipline of Endodontics, Department of Dentistry, School Integrated of Diamantina, FAFEID, Minas Gerais, Brazil.

2- DDS, MSc, PhD. Chairman, Department of Endodontics, School of Dentistry of Araraquara, UNESP, São Paulo, Brazil.

3- DDS, MSc, PhD, Chairman, Discipline of Pediatric Dentistry, Department of Pediatric, Preventive and Social Dentistry, School of Dentistry of Ribeirão Preto, USP, São Paulo, Brazil.

4- DDS, MSc, PhD. Associate Professor, Department of Endodontics, School of Dentistry of Araraquara, UNESP, São Paulo, Brazil.

5- DDS, MSc, PhD, Chairman, Discipline of Microbiology, School of Pharmaceutical Sciences of Ribeirão Preto, USP, São Paulo, Brazil.

Corresponding address: Janir Alves Soares - Faculdades Federais Integradas de Diamantina - Rua da Glória, 187 - Diamantina-MG. Cep.: 39.100.000 - E-mail: janirsoares@citel1.com.br - Tel: (38) 35312901

Received: September 22, 2004 - Accepted: November 11, 2004

\begin{abstract}
I

n the endodontic treatment of root canals with necrotic pulps associated with periapical radiolucent areas, one of the main objectives of treatment consists in eliminating the microorganisms spread throughout the ramifications of the root canal system. The scope of this study was to evaluate the antiseptic efficacy of biomechanical preparation and two calcium hydroxide-based pastes, in dogs' teeth with experimentally induced chronic periapical lesions. After initial microbiological sampling, instrumentation of the root canals was undertaken using the conventional technique, using $\mathrm{K}$ type files used in conjunction with a solution of $5.25 \%$ sodium hypochlorite. After ninety-six hours, further microbiological sampling was undertaken and Calen/CPMC or Calasept pastes were applied for 15 and 30 days. Ninety six hours after the removal of the medication, the third microbiological sampling was undertaken and finally histomicrobiological analysis followed using Brown \& Brenn staining. The results were analyzed using the Kruskall-Wallis test, with a level of significance established at $5 \%(\mathrm{p}<0.05)$. It was shown that the biomechanical preparation significantly reduced the number of colony forming units of microorganisms in root canals. In contrast, there was no significant difference between the antiseptic action of long-term dressings over two periods of action, although 30 days produced a greater reduction in the quantity of microorganisms and of positive microbiological cultures. In histological sections of the four experimental groups, similar microbiological patterns were shown ( $>>0.05)$, characterized by an elevated incidence of cocci, bacilli and filaments, predominantly gram-positive, in root canals, secondary canals and accessories, apical cementoplasts and dentinal tubules, but with a low incidence of microorganisms in areas of cementum resorption and the periapical lesion. The biomechanical preparation and intracanal dressing based on calcium hydroxide were important in the antisepsis of the root canal; however, both procedures did not produce significant changes in the microbiological aspects of the root canal system. Uniterms: Root canal therapy: Intracanal dressing; Microbiological culture; Calcium hydroxide pastes.
\end{abstract}

\section{RESUMO}

$N$

o tratamento endodôntico dos canais radiculares com polpa necrótica associados à áreas radiolúcidas periapicais, um dos principais objetivos consiste em eliminar os microrganismos situados em todo o sistema de ramificações. Por conseguinte, o objetivo deste estudo foi avaliar a eficácia anti-séptica do preparo biomecanico e de duas pastas à base de hidróxido de cálcio, em dentes de cães com reações periapicais crônicas experimentalmente induzidas. Após amostragem microbiológica inicial, realizou-se a instrumentação dos canais radiculares pela técnica convencional, utilizando-se limas tipo Kerr coadjuvadas pela solução de hipoclorito de sódio a 5,25\%. Noventa e seis horas após, obteve-se a segunda amostragem microbiológica e aplicou-se as pastas Calen/PMCC ou Calasept, por 15 e 30 dias. Noventa e seis horas após a remoção da medicação, obteve-se a terceira amostragem microbiológica e ulterior análise histomicrobiológica pela técnica de Brown \& Brenn. Os resultados foram analisados pelo teste de Kruskall-Wallis, com nível de significância estabelecido em $5 \%(p<0,05)$. Verificou-se que o preparo biomecânico reduziu significativamente o número de unidades formadoras de colônias de microrganismos. Em contrapartida, não houve diferença significativa entre a ação anti-séptica dos curativos de demora nos dois tempos de ação, embora aos 30 dias houvesse maior redução da quantidade de microrganismos e da incidência de culturas microbiológicas positivas. Nas seções histológicas dos quatro grupos experimentais, verificou-se similar padrão microbiológico, (p>0,05), caracterizado por elevada incidência de cocos, bacilos e filamentosos, predominantemente gram-positivos, situados no canal radicular, canais secundários e acessórios, cementoplastos apicais e túbulos dentinários, mas com baixa incidência de microrganismos nas áreas de reabsorção cementária e lesão periapical. O preparo biomecânico e o curativo de demora à base de hidróxido de cálcio foram importantes na anti-sepsia do canal radicular principal, contudo, ambos os procedimentos não proporcionaram significativas mudanças nos aspectos histomicrobiológicos do sistema de canais radiculares.

Unitermos: Tratamento de canal radicular; Medicação intracanal; Cultura microbiológica; Pastas de hidróxido de cálcio. 


\section{INTRODUCTION}

As a result of necrosis of the dental pulp, the pulp chamber becomes progressively colonized by microorganisms from the oral cavity and interconnected systems $^{19,22}$. Due to the intimate physio-pathological connection between the root apex and the periapical tissue, immuno-pathological mechanisms result in the formation of abscesses, cysts and periapical granulomas ${ }^{17,19,20}$. Using the technique of microbiological culture and Brown \& Brenn staining, it has been shown that the root canal represents the principal site of bacterial and fungal growth, from which microorganisms propagate throughout the system and its ramifications $s^{6,8,12,14,17}$. In these circumstances, one of the objectives of endodontic treatment consists of significantly reducing, inactivating or completely eliminating the endodontic infection, since there is a significant association between root canals microbiologically negative prior to root filling and the incidence of clinical and radiographic success ${ }^{18,20,22}$.

Biomechanical preparation, independent of the technique or type of irrigation used, provides significant reduction of the microbiota, but only in the main root canal ${ }^{6,13,14,18,20}$. Microorganisms remaining and those situated in secondary accessory canals and ramifications of the apical delta, dentinal tubules and apical cementoplasts, may re-infect the root canal after biomechanical preparation and maintain the periapical lesion after obturation of the root canal ${ }^{2,6,12,17,18,22}$. Consequently, the use of calcium hydroxidebased pastes has been widely recommended with the objective of applying a complementary antiseptic effect ${ }^{1-}$ 3,6,11,15-18,22. The antimicrobial activity of calcium hydroxide arises from its capacity to inactivate molecules fundamental for reproduction and metabolism of microorganisms, including structural proteins and enzymes, phospholipids and DNA ${ }^{15}$. For this to occur, there must be a dissociation and diffusion of hydroxyl ions and maintenance of alkalinity throughout the root structure ${ }^{1,3,9,17}$, where a $\mathrm{pH}$ plateau is obtained after approximately 14 days $^{3,9}$.

Taking into account that, in vitro, the different vehicles added to the calcium hydroxide influence its diffusion through the root canal system ${ }^{1,3,9,17}$ and consequently, their antiseptic performance ${ }^{5,16}$; this study had the objective of evaluating, comparatively, the microbiological and histomicrobiological conditions provided by biomechanical preparation and two long-term dressings based on calcium hydroxide, used for different periods of time, in dogs' root canals with experimentally induced chronic periapical lesions.

\section{MATERIALAND METHODS}

This study was conducted on 64 root canals from maxillary and mandibular premolars of four dogs aged 1 year old. The animals were injected intravenously with $3.0 \%$ sodium nembutal at a dose of $30 \mathrm{mg} / \mathrm{Kg}$ of body weight; premolar occlusal cavities were opened, the pulp tissues were carefully removed with a Hedströen file, and root canals were left exposed to the oral environment for 7 days for the purpose of contamination. After this period, the access openings were sealed with zinc oxide-eugenol cement (S.S. White, Rio de Janeiro, Brazil) to await the induction of periapical lesions. Standardized radiographs were taken at 15-day intervals to monitor the development of radiolucent periapical areas, suggestive of chronic periapical lesions, which usually occurred after 45 days. After isolation with a rubber dam, the tooth was disinfected with $70 \%$ alcohol and $0.3 \%$ iodine and the zinc oxide-eugenol cement was removed. Microbiological sampling of all root canals was performed by using three sterilized absorbent paper points which were transferred to reduced transport fluid (RTF). The progressive neutralization of the septic/toxic contents of the root canals was performed with K-files (Lês Fils Maillefer, Ballaigues, Switzerland) using a crown-down technique and irrigation with a solution of $5.25 \%$ sodium hypochlorite, using a syringe and 27 gauge needle. After establishing the working length, the apical patency was obtained sequentially along the length of the root canal using K-files to size 30, with 5.25\% sodium hypochlorite irrigation. During instrumentation, the root canals were enlarged and shaped with K-files and alternately irrigated with $3.6 \mathrm{~mL}$ of $5.25 \%$ sodium hypochlorite at every change of file. Working lengths were established at $2 \mathrm{~mm}$ short of the radiographic apex and the apical stop was enlarged to a \#60 K-file. After preparation, the root canals were filled with buffered $14.3 \%$ EDTA solution, which was agitated with a $\mathrm{K}$ file for $5 \mathrm{~min}$. The root canals were then irrigated with $3.6 \mathrm{~mL}$ of saline solution, dried with paper points and left empty and their access cavity sealed with zinc oxideeugenol cement. After 96 hours the second microbiological sampling was undertaken. The root canals were then filled with calcium hydroxide-containing pastes, either Calen/ CPMC or Calasept, for fifteen or thirty days, which formed the following groups: group I- Calen/CPMC for 15 days $(\mathrm{n}=14)$; group II- Calen/CPMC for 30 days $(\mathrm{n}=18)$; group IIICalasept for 15 days $(n=15)$ and group IV- Calasept for 30 days ( $n=17)$. The Calen/CPMC paste (S.S. White, Rio de Janeiro, Brazil) is composed of $2.5 \mathrm{~g}$ calcium hydroxide, $1 \mathrm{~g}$ zinc oxide p.a, $0.05 \mathrm{~g}$ colophony, $2 \mathrm{~mL}$ polyethylene glycol 400 , and $0.04 \mathrm{~g}$ of camphorated paramonochlorophenol, and was applied using a threaded syringe (ML endodontic syringe; S.S. White, Rio de Janeiro, Brazil) with a long gauge 27 needle (Teruno, Tokyo, Japan). The Calasept paste (Scania Dental AB-Knvist- Sweden) is composed of $56 \mathrm{~g}$ calcium hydroxide, 350mg sodium chloride, $8 \mathrm{mg}$ potassium chloride, $8 \mathrm{mg}$ calcium chloride, $4 \mathrm{mg}$ sodium carbonate and sterile isotonic saline. This paste was applied using the ML endodontic syringe and needle supplied by the manufacturer. The pulp chamber was dressed with a sterile cotton pellet and the crown opening was sealed with zinc oxide-eugenol cement; periapical radiograph was taken to verify the full filling of the root canal. After fifteen or thirteen days, the dressings were removed by master apical files aided by copious irrigation with $5.0 \mathrm{~mL}$ of saline solution, the canal was dried with paper points and once again sealed. After 96 hours, the third microbiological sampling was 
undertaken and the animals were sacrificed by anesthetic overdose. The maxilla and mandible were removed and the teeth were individually separated and fixed in a buffer solution of sodium cacodylate with saccharose and glutaraldehyde (Sigma, St. Louis, MO). Then followed demineralization with solution EDTA and glutaraldehyde activacted in a microwave oven (Sharp, São Paulo, SO, Brazil). The roots were then washed in running water for $24 \mathrm{~h}$, dehydrated by increasing concentrations of ethyl alcohol and cleared in xylol. After paraffin embedding, the tissue blocks were cut into serial 6-mm sections and stained by Brown \& Brenn method. The presence of microorganisms was evaluated in the 2-mm apex of the root canal, the dentinal tubules, apical delta, apical cementum and periapical region. Invasion of dentinal tubules by microorganisms was graded according to the criterion of Shovelton ${ }^{5}$ on the basis of the number of tubules invaded: mild grade, 1 to 20 tubules; moderate grade, 21 to 50 tubules; and severe grade, more than 51 tubules.

\section{Microbiological processing}

The tubes containing the microbiological samples received sterilized glass spheres, followed by mechanical shaking in a Mixtron-Toptronix apparatus (São Paulo, Brazil) for 2 minutes. The suspension was diluted with $1 / 15 \mathrm{M}$ saline containing buffered phosphate solution (PBS) at pH 7.0, in a decimal series until a concentration of $10^{-4}$, in a laminar flow hood. Aliquots of $0.05 \mathrm{~mL}$ were transferred to plates and the liquid spread into an L-shape with a glass rod. The plates contained the following culture media: blood agar (BA); mitis-salivarius agar (Ms); bacitracina sacarose agar (SB20); MacConkey agar (Mc) and hypertonic egg yolk agar (Ni). Approximately 3.0mL of thioglycollate broth (Tio's) without indicator and without dextrose (Difco, Detroit, MI), were added to the tubes containing the suspensions. Anaerobic incubation followed for 7 days, and then microaerophilic and aerobic conditions for 48 hours, at $37^{\circ} \mathrm{C}$. The BA medium with added hemine $(5 \mathrm{mg} / \mathrm{mL})$ and menadiona $(0.5 \mathrm{mg} / \mathrm{mL})$ was used to recover obligatory anaerobic microorganisms. The Ms medium permitted the growth of Streptococcus viridans (S. sanguis, S. mitis, S. salivarius and S. mutans). The Ni, SB20 and Mc media permitted the growth of Stafilococcus aureus, Streptococcus of the group mutans and gram-negative facultative bacillus entericus, respectively. The colony forming units (CFUs) were measured using a stereoscopic microscope.

\section{Statistical analysis}

Various hypotheses were statistically analyzed using the non-parametric model of Kruskall-Wallis, with a significance level established at $5 \%(\mathrm{p}<0.05)$. In this way, the following hypotheses $(\mathrm{H})$ were tested: $\mathrm{H} 1$ - if in each phase of microbiological evaluation the four groups presented equal frequencies of CFUs; H2- if each group presented equal numbers of CFUs in the three phases of microbiological evaluation; H3- if in each culture medium there were equal frequencies of positive cultures in the three phases of microbiological samples. H4- if the four groups showed similar patterns of infection of the root canal system and periapical region. For each hypothesis rejected, additional tests were undertaken to detect where a significant difference occurred.

\section{RESULTS}

\section{Microbiological culture}

Among the solid culture media, the microbiological growth was predominantly in BA and Ms, whose means of CFUs are expressed in Table 1 and 2. No growth occurred in media SB20 and Ni. In the initial sample, the obligatory anaerobes, Streptococcus viridans and gram-negative bacillus entericus, were recovered in $100.0 \%$, 89.0\% and 9.4\% of the root canals respectively. For the H1 hypothesis, all groups presented equal frequencies of CFUs in the three microbiological evaluations, except the Calen/CPMC group at 30 days, whose biomechanical preparation completely eliminated the obligatory anaerobic microorganisms, according to Table 1 . In relation to $\mathrm{H} 2$ hypothesis, biomechanical preparation was shown to result in a major reduction of CFUs of microorganisms $(\mathrm{p}<0.05)$. However, there was no significance difference between the CFUs obtained after biomechanical preparation and after removal

TABLE 1- Mean number of colony forming units of obligatory anaerobic microorganisms, in blood-agar culture medium, in the four experimental groups

\begin{tabular}{|c|c|c|c|c|c|}
\hline \multirow[t]{2}{*}{ Culture medium } & \multirow[t]{2}{*}{ Groups } & \multirow[t]{2}{*}{ Treatment } & \multicolumn{3}{|c|}{ Microbiological Samples } \\
\hline & & & $1^{\text {st }}$ & $2^{\text {nd }}$ & $3^{\text {rd }}$ \\
\hline & 1 & Calen/CPMC for 15 days & 14.428 .980 & 4.505 .008 & 5.500 \\
\hline Blood-agar & ॥ & Calen/CPMC for 30 days & 73.817 .934 & $0^{*}$ & 0 \\
\hline \multirow[t]{2}{*}{ (BA) } & III & Calasept for 15 days & 10.628 .364 & 974.4 .90 & 240 \\
\hline & N & Calasept for 30 days & 72.317 .824 & 4.507 & 0 \\
\hline
\end{tabular}

$1^{\text {st }}$ - Before biomechanical preparation $2^{\text {nd }}$. 96 hours after biomechanical preparation, $3^{\text {rd }}$ - 96 hours after removal of paste Based on calcium hydroxide, ${ }^{*}=$ Value statistically significant $(p<0.05)$ 
of long-term dressings ( $\mathrm{p}>0.05)$, according to Tables 1 and 2. In relation to the $\mathrm{H} 3$ hypothesis, applying the Chi-square test with 2 degrees of freedom $\left(\mathrm{Qq}_{0} 2\right)$, it was shown that the initial sample always showed the highest incidence of positive cultures. The Chi-square test with 1 degree of freedom $\left(\mathrm{Qq}_{\mathrm{o}} 1\right)$ revealed a significant reduction of positive cultures between the first and the third microbiological samples, according to Table 3.

\section{Histomicrobiological evaluation}

A total of 705 histological slices were obtained from single sampling of 47 dental roots, which were stained by the Brown \& Brenn method. According to Table 4, the microorganisms were predominantly identified in the cementum lacunae (91.4\%), canals of the apical delta (80.8\%) and dentinal tubules (55.3\%), with a lower incidence on the walls of the root canals (19.2\%), the periapical region(10.6\%) and areas of cementum resorption (4.2\%), with similar patterns of infection in the four experimental groups ( $p>0.05)$. According to Table 5 , the infection of dentinal tubules was predominantly mild (46.2\%) or severe (38.5\%), with only $15.3 \%$ showing a moderate type of infection. The Calen/ CPMC and the Calasept groups showed the greatest frequency of dentinal tubules with mild or severe infection, respectively, however, without statistical significance ( $>00.05$ ). The microbiological morphotypes most frequently observed in the root canal systems and the periapical region were cocci, bacilli and gram-positive filaments (Figures 1, 2, 3 and 4 ). Yeasts were identified in $8.7 \%$ of samples.

\section{DISCUSSION}

Although the microbiota isolated from root canals is composed of reduced numbers of bacterial species ${ }^{2,18,22}$, its complete elimination represents a real challenge. Such limitations arise especially from anatomical irregularities of the root canals, diffuse nature of infection through the system of ramifications, as well as the presence of blood, exudate and tissue remnants. These factors interfere with the efficacy of biomechanical techniques of preparation and

TABLE 2- Mean number of colony forming units of Streptococcus viridans in the agar culture medium mitis salivarius, in the four experimental groups

\begin{tabular}{|c|c|c|c|c|c|}
\hline \multirow[t]{2}{*}{ Culture medium } & \multirow[t]{2}{*}{ Groups } & \multirow[t]{2}{*}{ Treatment } & \multicolumn{3}{|c|}{ Microbiological Samples } \\
\hline & & & $1^{\text {st }}$ & $2^{\text {nd }}$ & $3^{\text {rd }}$ \\
\hline \multirow{4}{*}{$\begin{array}{l}\text { Mitis salivarius } \\
\text { agar (Ms) }\end{array}$} & 1 & Calen/CPMC for 15 days & 322.680 & 65.300 & 45 \\
\hline & $\|$ & Calen/CPMC for 30 days & 54.126 & 0 & 0 \\
\hline & III & Calasept for 15 days & 67.987 & 64.662 & 0 \\
\hline & $\mathrm{N}$ & Calasept for 30 days & 83.993 & 735 & 0 \\
\hline
\end{tabular}

TABLE 3- Frequencies of positive microbiological cultures in Tio's, BA and Ms culture medium as a function of treatment and the respective chi-squared values

\begin{tabular}{|c|c|c|c|c|c|c|c|c|c|c|}
\hline \multirow[t]{2}{*}{ Groups } & \multirow[t]{2}{*}{ Treatments } & \multirow{2}{*}{$\begin{array}{l}\text { Culture } \\
\text { medium }\end{array}$} & \multicolumn{6}{|c|}{ Microbiological Samples } & \multicolumn{2}{|c|}{ Chi-square } \\
\hline & & & \multicolumn{2}{|c|}{$1^{\text {st }}$} & \multicolumn{2}{|c|}{$2^{\text {nd }}$} & \multicolumn{2}{|c|}{$3^{\text {rd }}$} & $\mathrm{Qq}_{0} 2$ & $\mathrm{Qq}_{0} 1$ \\
\hline \multirow[t]{3}{*}{ I } & Calen/CPMC & Tio's & (14) & 100,0 & (7) & 50,0 & (5) & 35,7 & $13,52^{*}$ & $12,27^{*}$ \\
\hline & for 15 days & BA & (14) & 100,0 & (5) & 35,7 & (1) & 7,1 & $25,39 *$ & $24,20^{*}$ \\
\hline & & Ms & (13) & 92,9 & (3) & 21,4 & (1) & 7,1 & $24,51^{*}$ & $21,35^{\star}$ \\
\hline \multirow[t]{3}{*}{ II } & Calen/CPMC & Tio's & (18) & 100,0 & (9) & 50,0 & (4) & 22,2 & $18,99 *$ & $18,82^{*}$ \\
\hline & for 30 days & BA & (18) & 100,0 & (0) & 0,0 & $(0)$ & 0,0 & $48,00 *$ & $36,00^{*}$ \\
\hline & & Ms & (14) & 77,8 & (0) & 0,0 & (0) & 0,0 & $39,65^{*}$ & $9,88^{*}$ \\
\hline \multirow[t]{3}{*}{ III } & Calasept for & Tio's & (15) & 100,0 & (6) & 40,0 & (5) & 33,3 & $13,80 *$ & $9,07 *$ \\
\hline & 15 days & $\mathrm{BA}$ & (15) & 100,0 & (5) & 33,3 & (1) & 6,6 & $16,58^{*}$ & $11,06^{*}$ \\
\hline & & Ms & (14) & 93.3 & (4) & 26,7 & (0) & 0,0 & $28,89 *$ & $27,22^{\star}$ \\
\hline \multirow[t]{3}{*}{ N } & Calasept for & Tio's & (17) & 100,0 & (10) & 58,8 & (4) & 23,5 & $20,89 *$ & $20,85^{\star}$ \\
\hline & 30 days & BA & (17) & 100,0 & (2) & 11,8 & (0) & 0,0 & $43,45^{\star}$ & $36,36^{*}$ \\
\hline & & Ms & (16) & 94,1 & (1) & 5,9 & (0) & 0,0 & $42,53^{*}$ & $33,88^{*}$ \\
\hline
\end{tabular}

In parenthesis: absolute frequency; outside parenthesis: relative frequency; ${ }^{*}=$ significance value. 
of various types of antiseptics used, since the susceptibility of the endodontic microbiota to the direct action of antimicrobials used in endodontic treatment, such as 5.25\% sodium hypochlorite and of calcium hydroxide based pastes, ${ }^{2}$ is commonly evaluated in vitro and over relatively short periods of time $e^{4,7,10,15,16,21}$.

The antiseptic efficacy of biomechanical preparation and of calcium hydroxide-based pastes in this study was evaluated at four days after the respective procedures, when the root canals remained empty, and were sealed coronally. In this period, the microorganisms remaining in the main root canal and the system of ramifications proliferate and recolonize the walls of the root canals, being able to reach numerical levels equivalent to those found before endodontic treatment. Consequently, in these conditions, the sampling obtained from root canals represents the real microbiological conditions found throughout the root canal system. If samples are obtained immediately after biomechanical preparation and removal of calcium hydroxide paste, results would not be reliable $e^{2,17,18,22}$.

Thus, it has been shown that biomechanical preparation results in the greatest reduction of CFUs of obligatory anaerobes and of Streptococcus viridans, whose values oscillated between $68.8 \%$ and $100.0 \%$. It should be emphasized that $50.0 \%$ of infected root canals showed less than $30 \mathrm{CFUs} / \mathrm{mL}$. This antimicrobial effect is possibly due to the interaction of mechanical and chemical factors, for example with the greatest enlargement of the root canal; the frequency, quantity, method of irrigation, type and concentration of irrigant used 8 ,11-13,17,19.

All long-term dressings offer a complementary antiseptic action to the biomechanical preparation or maintain the antisepsis already obtained. Thus, a reduction was shown in the means of CFUs in the order of $99.06 \%$ to $100.0 \%$. Linked to the low incidence of positive cultures, a reduction was also found in the quantity of microorganisms in these root canals, since the incidence of samples with a quantity of bacteria less than 30 CFUs declined from $50.0 \%$ to $28.1 \%$. Although without significant difference, throughout the 30 days the long-term dressings showed the best antiseptic performance; possibly due to the maintenance of alkalinity for a longer time ${ }^{7,15}$. Based on the fact that the antibacterial effect of calcium hydroxide is due to the action of hydroxyl ions, it can be inferred that the vehicles of these two pastes, distilled water and polyethylene glycol, allow a similar dissociation and ion diffusion.

After the antiseptic procedures in the root canals, no significant difference was found between the four types of treatment used, whether evaluated through culture or Brown \& Brenn staining. The Brown \& Brenn staining is very important, since it evaluated the distribution of microorganisms in different endodontic sites, while microbiological culture allowed the quantification and identification of metabolically active microorganisms. Consequently, the histological slices frequently confirmed the presence of the morphotypes; cocci, bacilli and grampositive filaments in the canals of the apical delta, cementoplasts, in dentinal tubules and on the walls of the root canals. The root canals were evaluated by both microbial culture and by Brown \& Brenn staining, which showed a comparatively larger percentage of positive samples of microorganisms in histological sections, from which we can infer that many of these microorganisms were dead or in smaller quantities than could be detected by microbiological culture. Furthermore, in relation to the infection of dentinal tubules in comparison to histological sections of human teeth with associated apical granulomas and without endodontic treatment, it was shown that the pattern of infection of the dentinal tubules was classified as mild, moderate or severe in $31.4 \%, 22.9 \%$ and $20.0 \%$ of samples, respectively ${ }^{14}$. In the present study, these values were in the order of $46.0 \%, 15.4 \%$ and $38.4 \%$, respectively.

TABLE 5- Pattern of dentinal tubule infection, according to Shovelton ${ }^{14}$

\begin{tabular}{llll}
\hline Groups & Mild & Moderate & Severe \\
\hline I & (5) $71.4 \%$ & (0) $0.0 \%$ & (2) $28.6 \%$ \\
II & (3) $50.0 \%$ & (1) $16.7 \%$ & (2) $33.3 \%$ \\
III & (2) $25.0 \%$ & (2) $25.0 \%$ & (4) $50.0 \%$ \\
N & (2) $40.0 \%$ & (1) $20.0 \%$ & (2) $40.0 \%$ \\
\hline
\end{tabular}

TABLE 4- Distribution of microorganisms in the apical $2.0 \mathrm{~mm}$ of the root canal system and periapical region

\begin{tabular}{|c|c|c|c|c|c|c|}
\hline Groups & $\begin{array}{l}\text { Cement } \\
\text { lacunae }\end{array}$ & Apical delta & $\begin{array}{l}\text { Dentinal } \\
\text { tubules }\end{array}$ & $\begin{array}{l}\text { Walls of } \\
\text { root canal }\end{array}$ & $\begin{array}{l}\text { Periapical } \\
\text { region }\end{array}$ & $\begin{array}{l}\text { Areas of } \\
\text { resorption }\end{array}$ \\
\hline $\begin{array}{l}\text { I } \\
(n=12)\end{array}$ & $\begin{array}{l}11 \\
(91.6 \%)\end{array}$ & $\begin{array}{l}11 \\
(91.6)\end{array}$ & $\begin{array}{l}7 \\
(58.3 \%)\end{array}$ & $\begin{array}{l}3 \\
(25.0 \%)\end{array}$ & $\begin{array}{l}2 \\
(16.6 \%)\end{array}$ & $\begin{array}{l}2 \\
(16.6 \%)\end{array}$ \\
\hline $\begin{array}{l}\text { II } \\
(n=13)\end{array}$ & $\begin{array}{l}11 \\
(84.6 \%)\end{array}$ & $\begin{array}{l}9 \\
(69.2 \%)\end{array}$ & $\begin{array}{l}6 \\
(46.2 \%)\end{array}$ & $\begin{array}{l}2 \\
(15.3 \%)\end{array}$ & $\begin{array}{l}2 \\
(15.3 \%)\end{array}$ & $\begin{array}{l}0 \\
(0 \%)\end{array}$ \\
\hline $\begin{array}{l}\text { III } \\
(n=11)\end{array}$ & $\begin{array}{l}10 \\
(90.9 \%)\end{array}$ & $\begin{array}{l}7 \\
(63.6)\end{array}$ & $\begin{array}{l}8 \\
(72.7 \%)\end{array}$ & $\begin{array}{l}1 \\
(9.0 \%)\end{array}$ & $\begin{array}{l}1 \\
(9.0 \%)\end{array}$ & $\begin{array}{l}0 \\
(0 \%)\end{array}$ \\
\hline $\begin{array}{l}N \\
(n=11)\end{array}$ & $\begin{array}{l}11 \\
(100.0 \%)\end{array}$ & $\begin{array}{l}11 \\
(100.0 \%)\end{array}$ & $\begin{array}{l}5 \\
(45.4 \%)\end{array}$ & $\begin{array}{l}3 \\
(27.2 \%)\end{array}$ & $\begin{array}{l}0 \\
(0 \%)\end{array}$ & $\begin{array}{l}0 \\
(0 \%)\end{array}$ \\
\hline
\end{tabular}




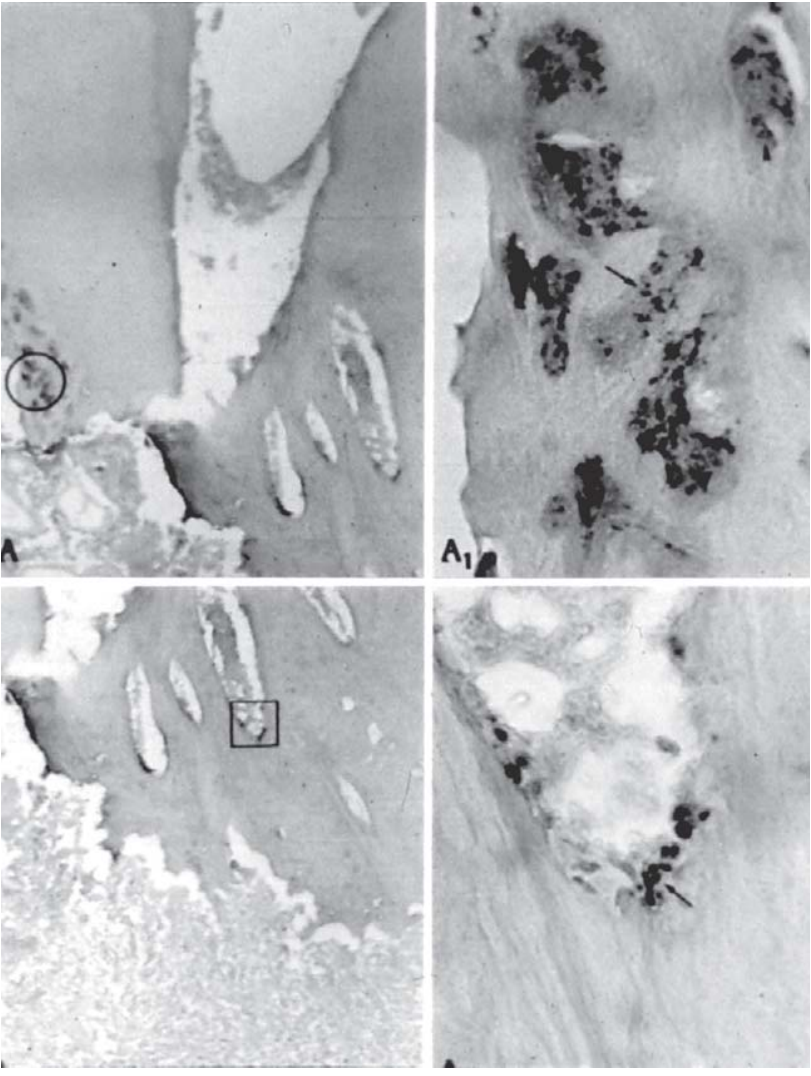

FIGURE 1- Group I: A- Microorganisms in cementum lacunae (circle) and canals of the apical delta - 125x. A1Innumerable gram-positive cocci and bacilli can be seen 1000x. A2- Canals of the apical delta (square) with microorganisms - 125x. A3- Presence of yeast - 1000x. Brown \& Brenn staining

Thus, comparatively, the infection of dentinal tubules of teeth without endodontic treatment was not notably different from the results of the present study, in which the root canals received biomechanical preparation and calcium hydroxide paste-based dressings. Consequently, many of the microorganisms seen in the various histological sections may have been dead or have lost the reproductive capacity. Hence, in histomicrobiological terms, the effectiveness of an intracanal antiseptic does not necessarily mean the absence, that is, the destruction of microorganisms in tissues. Due to this fact, trustworthy conclusions can only be obtained by microbiological culture of the root structure ${ }^{12}$.

The root canals treated with Calasept paste had the largest presence of bacteria in the dentinal tubules compared to Calen/CPMC paste, which were predominantly grampositive cocci. Some of these microorganisms may have been Enterococcus faecalis, since the aqueous calcium hydroxide paste is ineffective against such bacteria situated in dentinal tubules ${ }^{4,10}$, while a better performance was observed for $\mathrm{CPMC}^{10}$ or calcium hydroxide/CPMC ${ }^{15}$. The resistance of some microorganisms to calcium hydroxide has been partly attributed to the fact that dentine has a buffering system towards hydroxyl ions ${ }^{2}$, impeding the increase in $\mathrm{pH}$ to a lethal value, which for Enterococcus faecalis is above $\mathrm{pH}=11.5$. In other situations the presence

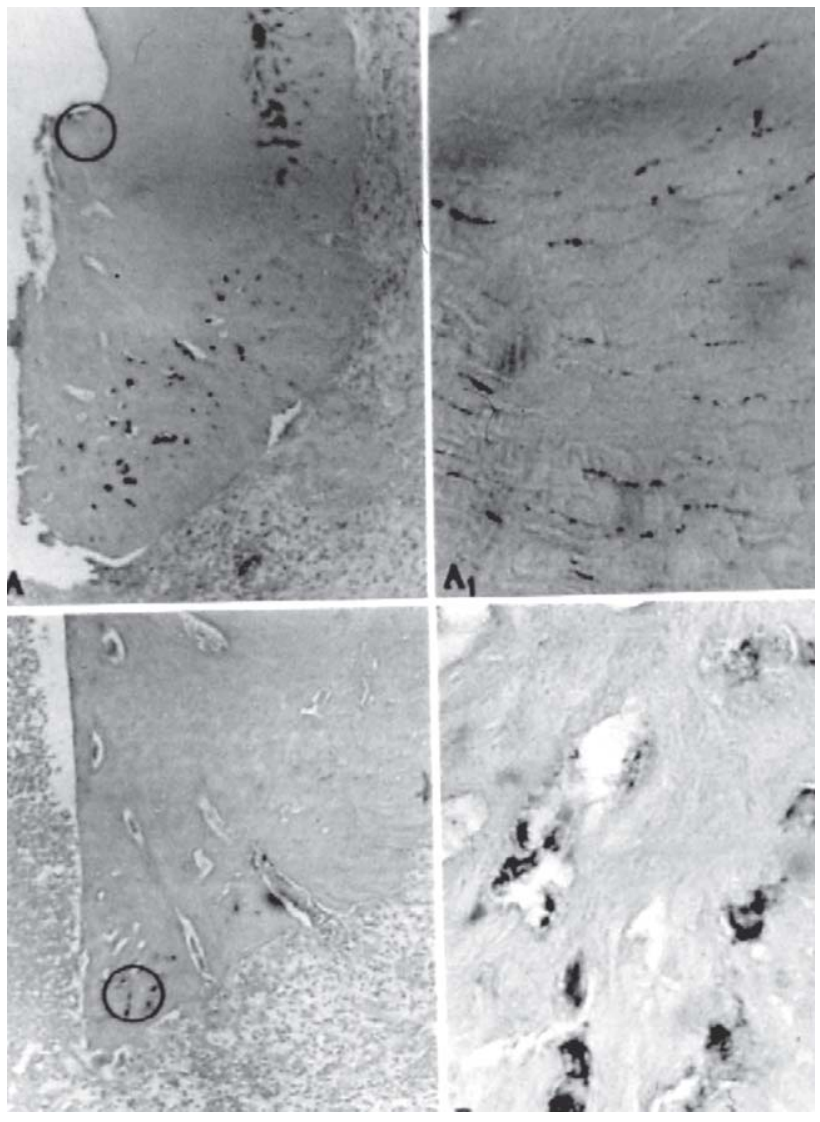

FIGURE 2- Group II: A- Innumerable cementum lacunae and dentinal tubules (circle) containing microorganisms. 125x. A1- Propagation of gram-positive cocci through dentinal tubules - 1000x. B- Microorganisms in the cementum lacunae (circle) and canals of the apical delta125x. B1- Gram-positive and negative cocci and bacilli in cementoplasts - 1000x. Brown \& Brenn staining

of cellular mechanisms may assign resistance at certain levels of alkalinity ${ }^{2,5}$.

Four days after removal of the long-term dressings, which were in place for 30 days, it was still possible to detect microorganisms in approximately $28.1 \%$ of specimens, which possibly adhered to apical ramifications and dentinal tubules. Such remaining microorganisms deserve more therapeutic emphasis, since even though present in small quantities, they may, with the passage of time, proliferate reaching quantities similar to the original levels ${ }^{2,18,22}$. Furthermore, if root canals are sealed in these conditions, some species may reach the periapical area due to microleakage through the margins of the obturations, canals of the apical delta and/ or dentinal tubules exposed by cementum resorption $^{6,17}$. Such microbiological conditions possibly contribute to the partial resolution or persistence of endodontic signs and symptoms after root canal obturation $^{6,12,18,22}$. Therefore, from a microbiological viewpoint, not only the clinical and radiographic, but above all the histopathological resolution of chronic periapical lesions depends on substantial improvements to existing antiseptic procedures for the root canal system. In this respect, we are undertaking in vivo studies evaluating 


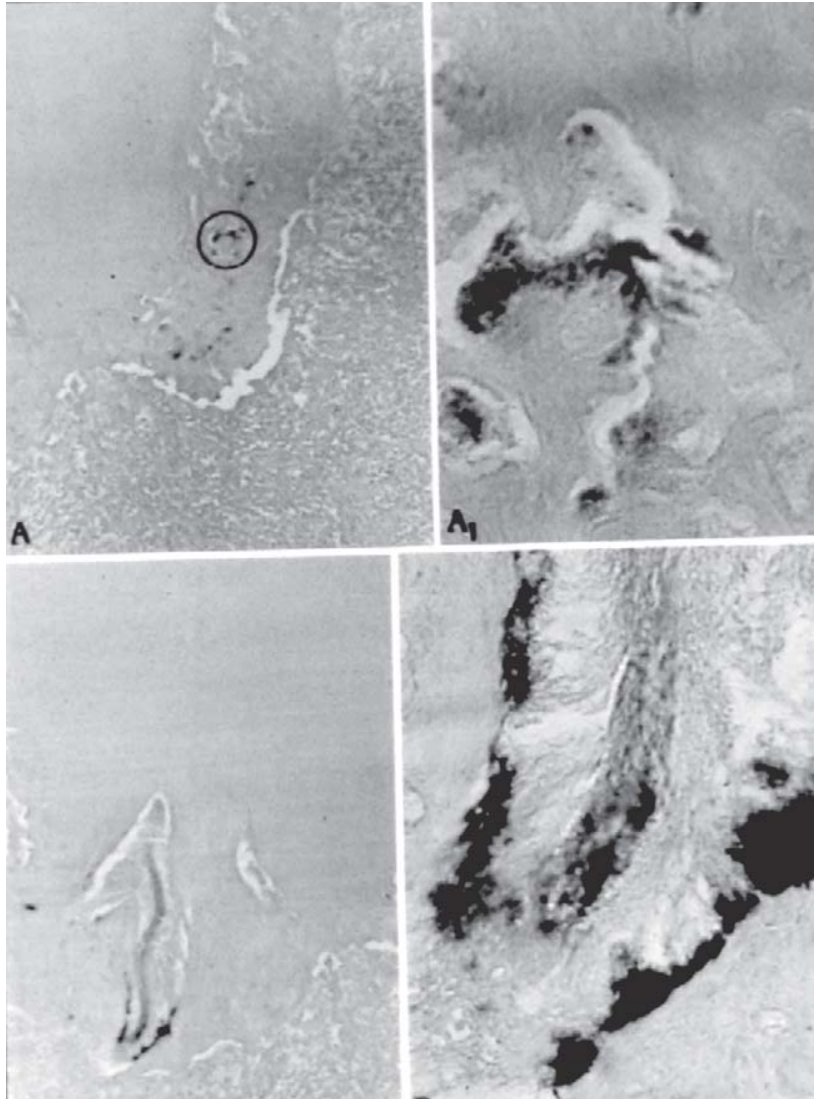

FIGURE 3- Group III: A- Cementum lacunae (circle) containing microorganisms - 125x. A1- Numerous grampositive microorganisms in the cementum lacunae 1000x. B- Microorganisms in the canal of the apical delta 125x. B1- Gram-positive filaments (small arrow) and grampositive cocci (large arrow). 1000x. Brown \& Brenn staining

complementary antisepsis to calcium hydroxide pastes by additions of other antiseptics, such as chlorhexidine digluconate.

\section{CONCLUSIONS}

1- Teeth with necrotic pulp and radiolucent periapical areas show elevated numbers of obligatory anaerobic microorganisms present in the root canals.

2- Biomechanical preparation aided by irrigation with a solution of $5.25 \%$ sodium hypochlorite significantly reduced the microbiota of the root canals.

3- Calen/CPMC and Calasept paste show similar antimicrobial performance, independent of the time they are present in the root canal, although 30 days showed the greatest reduction or elimination of microorganisms.

4- Histomicrobiological aspects of the root canal system and periapical region do not show significant differences as a function of different procedures of antisepsis used.

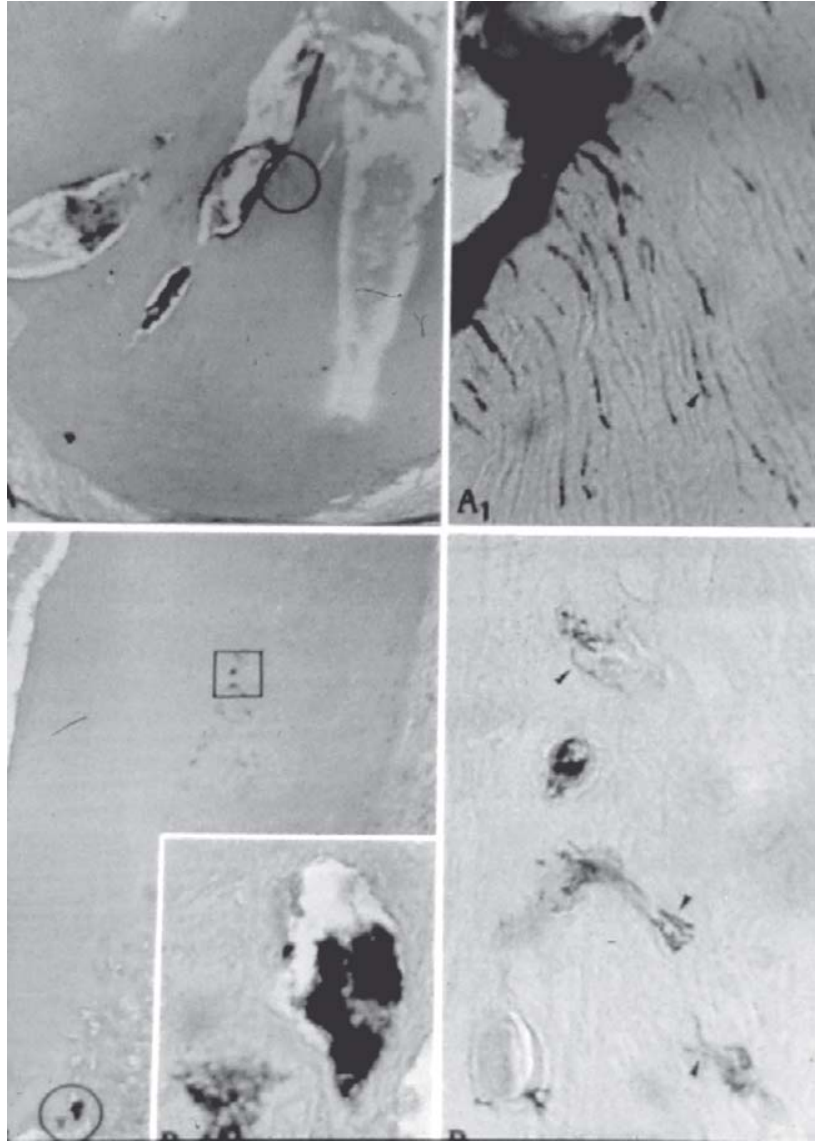

FIGURE 4- Group IV: A- Microorganisms in the canal of the apical delta - 125x. A1- Severely infected dentinal tubules1000x. B- Microorganisms in the cementum lacunae - 125x. B1 and B2- Cementoplasts with numerous cocci, bacilli and gram-positive filaments - 1000x. Brown \& Brenn staining

\section{REFERENCES}

1-Alaçam TH, Yoldas O, Gulen O. Dentin penetration of 2 calcium hydroxide combinations. Oral Surg 1998;86:469-72.

2-Bystrom A, Claesson R, Sundqvist G. The antibacterial effect of camphorated para-monochlorophenol, camphorated phenol and calcium hydroxide in the treatment of infected root canals. Endod Dental Traumatol 1985;1:170-5.

3-Esberard RM, Carnes DL, Del Rio CE. Changes in $\mathrm{pH}$ at the dentin surface in roots obturated with calcium hydroxide pastes. J Endod 1996;22:402-5.

4-Estrela C, Pimenta FC, Ito IY, Bammann LL. Antimicrobial evaluation of calcium hydroxide in infected dentinal tubules. J Endod 1999;25:416-8.

5-Han GY, Park S-H, Yoon TC. Antimicrobial activity of $\mathrm{Ca}(\mathrm{OH})_{2}$ containing pastes with Enterococcus faecalis in vitro. J Endod 2001;27:328-32.

6-Leonardo MR, Almeida WA, Ito IY, Silva LAB. Radiographic and microbiologic evaluation of posttreatment apical and periapical repair of root canals of dog's teeth with experimentally induced chronic lesion. Oral Surg Oral Med Oral Pathol 1994;78:232-8.

7-Leonardo MR, Silva LAB, Tanomaru Filho M, Bonifácio KC, Ito IY. In vitro evaluation of antimicrobial activity of sealers and pastes used in endodontics. J. Endod 2000;26:391-4. 
8-Matsumiya S, Kitamura M. Histo-pathological and histobacteriological studies of the relation between the condition of sterilization of the interior of the root canal and the healing process of periapical tissues in experimentally infected root canal treatment. Bull Tokyo Dent Coll 1960;1:1-19.

9-Nerwich A, Fidgor D, Endo D, Messer HH. pH changes in root dentin over a 4-week period following root canal dressing with calcium hydroxide. J Endod 1993;19:302-6.

10-Orstavik D, Haapasalo M. Disinfection by endodontic irrigants and dressings of experimentally infected dentinal tubules. Endod Dent Traumatol 1990;6:42-9.

11-Orstavik D, Kerekes K, Molven O. Effects of extensive apical reaming and calcium hydroxide dressing on bacterial infection during treatment of apical periodontitis: a pilot sutudy. Int Endod J 1991;24:1-7.

12-Peters LB, Wesselink PR, Buijs JF, Winkelhoff AJ. Viable bacteria in root dentinal tubules of teeth with apical periodontitis. J Endod 2001;27:76-81.

13-Rodrigues HH, Biffi JC. A histobacteriological assessment of nonvital teeth after ultrasonic root canal instrumentation. Endod Dent Traumatol 1989;5:182-7.

14-Shovelton DS. The presence and distribution of microorganisms within non-vital teeth. Br Dent J 1964;117:101-7.

15-Siqueira Jr JF, Lopes HP. Mechanisms of antimicrobial activity of calcium hydroxide: a critical review. Int. Endod J 1999;32:361-9.

16-Siqueira JR, JF, Uzeda M. Disinfection by calcium hydroxide pastes of dentinal tubules infected with two obligate and one facultative anaerobic bacteria. J Endod 1996;22:674-6.

17-Silveira FF, Leonardo MR, Ito IY, Silva LAB, Tanomaru Filho M. Avaliação histomicrobiológica após curativo de demora com pastas à base de hidróxido de cálcio por diferentes períodos de tempo. RBO 2001;58:224-6.

18-Sjögren U, Fidgor D, Persson S, Sundqvist G. Influence of infection at the time of root filling on the outcome of endodontic treatment of teeth with apical periodontitis. Int Endod J 1997;30:297-306.

19-Soares JA. Microbiota dos canais radiculares associada às lesões periapicais crônicas e sua significância clínica. JBE 2002;3(9):10617.

20-Soares JA, César CAS. Avaliação clínica e radiográfica do tratamento endodôntico em sessão única de dentes com lesões periapicais crônicas. Pesq Odont Bras 2001;15(2):138-44.

21-Spratt DA, Pratten J, Gulabilava K. An in vitro evaluation of the antimicrobial efficacy of irrigants on biofilms of root canals isolates. Int Endod J 2001;34:300-7.

22-Sundqvist G, Fidgor D, Persson S, Sjögren U. Microbiological analysis of teeth with failed endodontic treatment and the outcome of conservative re-treatment. Oral Surg 1998;85:86-93. 